\title{
AS CATEGORIAS PEDAGÓGICAS NO BRASIL BARROCO: um estudo sobre os sermões jesuíticos
}

\author{
Ana Palmira Bittencourt Santos Casimiro ${ }^{1}$
}

\section{RESUMO:}

No século XVIII, uma mentalidade comum, conformada pela religião e pela estética barroca reinava, uniformizando pensamentos e crenças. Como agentes dessas ideologias e mentalidades, estavam o Estado Português, que agia como elemento regulador da sociedade, e a Igreja Católica, que educava e evangelizava. O presente trabalho analisa as relações entre a religião católica e a educação no Brasil Colonial, a partir de sermões jesuíticos. Dos textos, foram extraídas e agrupadas categorias pedagógicas, advindas da teologia moral e bastante usadas naquele tempo, como: bons e maus exemplos, medos e ameaças, moderação e dosagem nos conteúdos. A análise indica que os sermões proferidos pelos padres da Companhia de Jesus adquiriam várias tonalidades: advertências, comparações, acusações, admoestações, exortações, conselhos e persuasão. Tudo isso no mais puro estilo barroco, o mais adequado para ser compreendido naquele tempo e lugar. Tais categorias pedagógicas foram eficazes na conscientização dos senhores para melhor preservação da mão-de-obra escrava, para submissão dos povos dominados e para a catalização de conflitos decorrentes daquela sociedade violenta, tendo em vista "Dilatar a Fé e o Império".

Palavras-Chave: Brasil. Ordens Religiosas. Jesuítas. Evangelização.Categorias Pedagógicas.

\section{THE PEDAGOGIC CATEGORIES IN BAROQUE BRAZIL: a study of the Jesuit sermons}

\begin{abstract}
:
In the eighteenth century, a common mentality, conformed by religion and baroque aesthetic reigned, standardizing thoughts and beliefs. As agents of these ideologies and mentalities, in unison, were the Portuguese State, who acted as a regulatory element of society and the Catholic Church, which educated and evangelized. This paper analyzes the relations between the Catholic religion and education in colonial Brazil, from Jesuit sermons. From the texts, were extracted and grouped educational categories, arising from the moral theology and used extensively at the time, as good and bad examples, fears and threats, restraint and strength in content. The analysis indicates that the sermons delivered by Fathers of the Society of Jesus took on various shades: warnings, comparisons, charges, admonition, exhortation, advice and persuasion. All this in pure Baroque style, best suited to be understood at the time and place. These categories were effective in teaching awareness of slaveholders to better preservation of the slave labor, for the submission of the dominated peoples and a catalyst for the conflicts arising from that violent society in order "To spread the faith and the Empire."

Key-Words: Brazil. Religious groups. Jesuits. Evangelization. Pedagogic Categories.
\end{abstract}




\section{O Brasil Barroco}

Duzentos anos depois do descobrimento, no início do século XVIII, a paisagem brasileiraErro! Indicador não definido. se configurava em grupos diferenciados pela cor, pela classe social e por ideologias e mentalidades variadas. Não obstante, uma mentalidade comum, conformada pela religião e pela estética barroca (ÁVILA, 1980), reinava, uniformizando pensamentos e crenças. Como agentes dessas ideologias e mentalidades, junto com o Estado Português e a Igreja Católica, estavam as ordens religiosas (com destaque para a Companhia de Jesus), e seus missionários, que agiam como elemento regulador da sociedade, cumprindo e fazendo cumprir uma série de leis, ordenações, alvarás e provisões reais, portarias e estatutos coloniais, normas eclesiásticas, conciliares e inquisitoriais.

Ao lado desse aparato legal, havia uma enorme gama de modelos a serem seguidos para a instauração e o bom desenvolvimento do projeto colonial, e para as regras do bem viver cotidiano. Eram regras de submissão ao rei, de atitudes, de comportamento civil e religioso, regras nas relações familiares, práticas sociais, afetivas e sexuais, regras no falar e no calar, na ação e no pensamento. Eram condutas morais e modelos ideais de comportamento, aproximando os indivíduos das verdades da Igreja Católica e da vontade do rei, mas, sempre, visando à disciplina social e a manutenção do status quo.

Esse quadro social consolidou-se com o uso da força e de mecanismos ideológicos representados por escritos, cartas e relatórios, emitidos pelas camadas oficiais letradas e eruditas. Inúmera documentação pode comprovar tal política, a exemplo das Ordenações Filipinas, das Constituições Primeiras do Arcebispado da Bahia, Cartas da Câmara e do Senado, cartas dos jesuítas e de outros religiosos, crônicas e descrições de viajantes, testamentos, processos judiciais, etc.

As Constituições Primeiras do Arcebispado da Bahia, por exemplo, foram promulgadas em 1707, "para o bom governo do Arcebispado, direção dos costumes, extirpação dos vícios e abusos, moderação dos crimes, e recta administração da justiça" (VIDE, 1853, p.XVI). O seu texto determinava o comportamento dos fiéis e do clero. As Constituições revelam, em todo o seu teor, um complexo controle sobre as regras, atitudes, normas e culto religioso, assim como sobre os bens materiais da Igreja e sobre a conduta, pública e privada dos fiéis, garantindo, essencialmente, a sobrevivência da própria Igreja. Seu estilo, forma e conteúdo, contêm três propriedades constantes, em todo o texto: a) a jurisprudência, a lei e a ordem; b) a punição religiosa e (ou) pecuniária; c) a fundamentação doutrinária, de caráter ideológico. Possuía, só a título de exemplo, 144 tipos de excomunhão.

Todos deveriam submeter-se àquelas regras que eram impostas, sendo a desobediência passível de punição. O próprio clero era destinatário de enormes parágrafos. Por essa razão, os colonos procuravam participar dos ofícios religiosos e do exercício da fé cristã, assistindo à missa, pagando seus dízimos, confessando, rezando pelos seus mortos e prevenindo a salvação das suas almas. Inclusive, deixavam legados para a celebração de missas post mortem. Buscavam, assim, encontrar apoio e conforto espiritual, diante da instabilidade de suas vidas e ansiando pela salvação após as suas mortes.

A sociedade era, mais ou menos, obediente e submissa aos modelos implantados, mas, algumas pessoas, voluntária ou involuntariamente, entravam em conflito com o sistema. Em grupo ou individualmente, de forma clandestina ou às claras, tais pessoas, quando descobertas, eram punidas conforme podemos observar nos inúmeros processos da Inquisição. Processos no campo sexual, como bigamia, poligamia, concubinato, freiratice, adultério, prostituição, cafetinagem, sodomia e bestialismo etc. Ronaldo Vainfas (1989, p.92.) observou que tais formas de manifestações de sexualidade deviam-se à situação de 
"mulheres e homens enfadados no casamento; de padres mal afeitos ao celibato; de homens de prestígio que, na falta de mulheres 'brancas e honradas', uniram-se às mulheres de cor; de mulheres brancas, negras, índias ou mestiças que, 'solteiras', não podiam encontrar marido".

Apesar de a população estar submetida às mesmas normas e prescrições religiosas e civis, as formas de julgamento, penas e punições eram diferentes conforme a classe social do infrator. Às classes dominantes geralmente incidiam penas pecuniárias, degredos ou, no mínimo, morosidade nos processos; aos clérigos, cabia transferências ou disciplinamento religioso dentro da própria ordem. Às classes dominadas, principalmente aos pobres e aos escravizados incidiam humilhações públicas, açoites, aljube, torturas, pelourinho, mutilações, galés e morte. Curiosamente, havia sempre novas práticas e muitas reincidências dos mesmos tipos de crimes (VAINFAS, 1989, p.52).

Tal organização colonial delineou as ideologias reinantes e a mentalidade do homem de então se forjou, segundo o princípio barroco da contradição: religião contraditória, humanismo contraditório e sentimentos contraditórios, que comportavam a existência de ricos e pobres, brancos e negros; honra e desonra, agiotas e mendigos; cristãos e hereges, Deus e o demônio - todos em dualidades antagônicas. A minoria privilegiada aceitava esses posicionamentos, prestando obediência e submissão inquestionáveis ao modelo português de uma sociedade dita cristã. A maioria, quando possível, transgredia.

No campo dos costumes, prevaleciam traços da herança medieval e, sobretudo, elementos da mentalidade portuguesa, acrescidos dos traços culturais africanos e ameríndios. No campo pedagógico, prevalecia forte inspiração religiosa, mesmo quando se tratava do ensino de conteúdos laicos. A forma como esses conteúdos eram transmitidos era, essencialmente, barroca e se expressava nas obras de artes plásticas, na música e na oratória. Também estavam presentes nos conteúdos educacionais, fossem eles humanidades ou religião.

O imaginário colonial, povoado de anjos e demônios, expressava-se conforme a tragicidade barroca e deixava ao desamparo, o homem colonial. Aterrorizado, o homem daquele tempo sofria todo o tipo de medo. Os motivos advinham das crenças medievais em monstros, sereias e dragões, e da certeza da existência de bruxas, feiticeiras, sortilégios, mandingas. No que diz respeito ao medo de demônios, essas crenças populares eram perpetuadas e aproveitadas pela Igreja para amedrontar e dominar e, por vezes, eram até acreditadas por muitos membros do clero. $\mathrm{O}$ fator medo era utilizado por camadas mais humildes da população, como tentativa, também, de dominação e como armas nos conflitos sociais. Ou, simplesmente, como atividade profissional, na luta pela sobrevivência.

No caso dos escravizados, além do medo das surras, dos açoites, do pelourinho e da morte, estes temiam, também, as violências físicas e sexuais, principalmente as mulheres, vítimas dos caprichos dos senhores e do ciúme e da crueldade das senhoras. No geral, os escravos sentiam muito medo das violências dos senhores. Violências que eram, muitas vezes, sacralizadas como obra de misericórdia, por segmentos do clero, como demonstram os conselhos do Jesuíta Benci (1977, p. 165), em 1700: "Para trazer bem domados e disciplinados os escravos é necessário que o senhor lhes não falte com o castigo [...] Haja açoites, haja correntes e grilhões, tudo a seu tempo e com regra e moderação devida; e vereis como em breve tempo fica domada a rebeldia dos servos".

Os religiosos pressentiam o alcance e a eficácia das suas ameaças naquele território tão calejado, onde predominavam o medo dos castigos, sevícias e torturas, no plano físico; e o medo da perdição da alma, do demônio e do fogo do inferno, no plano 
espiritual. Além disso, havia, ainda, o medo das inquirições do Santo Ofício; o medo da fome, das doenças, do pecado, da morte e, principalmente, o medo do fogo eterno.

Duas das categorias pedagógicas mais utilizadas naquele tempo dizem respeito justamente às ameaças que pairavam sobre as cabeças dos homens coloniais e os medos que eles padeciam. $\mathrm{O}$ medo encontrava caminhos abertos naquelas mentes aterrorizadas pela religiosidade da época. Pela ordem, o maior medo que se tinha naquele tempo era da morte. Depois, o medo de morrer em pecado mortal Erro! Indicador não definido. medo este, incentivado pelas práticas e sermões religiosos. Finalmente, o medo do fogo eterno dos infernos.

Um dos medos mais comuns no imaginário do homem colonial era o medo do demônio. Demônio que foi 'visto' por inúmeras pessoas e que aparecia, em forma de mulher, de homem; por vezes com pés de cabra, de lebre ou pata, que possuía sexualmente homens e mulheres. Havia o medo das bruxarias, feitiçarias, sortilégios e mandingas, práticas estas muito comuns às prostitutas e cafetinas que mal sobreviviam naquelas profissões, mas que se viam impossibilitadas de professarem outras (VAINFAS, 1989, p.61).

Por conta do medo, a submissão ao modelo português mais do que obrigada era cultivada. Para o colono, essa submissão acontecia, também, pela tentativa de integrar-se socialmente. Integrar-se significava, em primeiro lugar, incorporar-se, agrupar-se com seus iguais e adequar-se à sociedade. Mas, qualquer tentativa de integração social passava pelas asas protetoras e dominadoras da religião católica, e pelas concepções pedagógicas das suas hostes.

Eduardo Hoornaert (1983, p.146) bem interpreta o papel desempenhado pela Igreja Católica no Brasil Colônia quando considera, independentemente da prática das virtudes, o caráter redutivo que assumiu a evangelização no Brasil. Uma vez que a evangelização significou no plano ideológico o que a escravidão significou no plano econômico, pois, nas palavras do autor, “reduzir o 'outro' ao 'mesmo' pelos discursos, ritos e símbolos fazia parte de um plano econômico, que visava reduzir o índio 'brabo', inapto ao trabalho a um índio "manso' perfeitamente integrado" no mundo que o português veio implantar no Brasil.

Os discursos religiosos, tanto os sermões como os textos escritos de teologia moral, são uma prova considerável dessa ação estética e ideológica. Nestes, é difícil se identificar onde termina a forma e começa o conteúdo, ambos barrocos, e vice-versa. Destarte, o quadro social e cultural que se consolidou no Brasil colonial favoreceu o desenvolvimento de uma mentalidade contraditória, peculiar à Colônia e que direcionara fortemente a pedagogia implantada nos colégios, nas famílias, nas missões ou na senzala.

\section{Um Modelo Jesuítico para a Educação de Senhores e Escravos}

A Economia Cristã dos Senhores no Governo dos Escravos, livro escrito pelo Jesuíta italiano Jorge Benci, a exemplo de outras obras de jesuítas e moralistas coloniais ${ }^{2}$, dá a conhecer aspectos metodológicos intrinsecamente ligados às categorias mentais daquela época. Tais aspectos aparecem distribuídos no texto benciano, indubitavelmente barroco, como uma profusão de categorias esparsas, porém, subordinadas à finalidade central da obra: estabelecer uma doutrina que resolvesse a 'desordem' da escravidão colonial. A linguagem usada pelo autor era a única passível de ser compreendida e decodificada pelos leitores daquela época. Aliás, saber decodificá-la fazia parte das capacidades mentais do homem barroco.

O livro do Jesuíta Benci, que resulta de sermões transformados em livro, publicado em $1700^{3}$, ao mesmo tempo em que apresenta normas orientadoras no trato com 
os escravos, propõe uma dupla pedagogia a qual orienta os senhores e preconiza uma educação para o escravo, desdobrada em categorias pedagógicas extraídas do Eclesiástico, a partir de três obrigações que o senhor deve ter para com o escravo: ' $O$ trabalho, o sustento e o castigo'. A essas categorias, Jorge Benci acrescentou uma quarta que ele chamou o 'pão da doutrina'(CASIMIRO, 2002).

Benci se inspira na Bíblia, a qual ele utilizou como fonte primária ou segundo interpretações patrísticas e escolásticas. O Jesuíta tenta aplicar o modelo anticotestamentário à realidade escravocrata. Acompanhando a reflexão e a construção argumentativa do autor, verificamos que ele preconiza uma pedagogia para os senhores no trato com os escravos, segundo a sabedoria tradicional dos Provérbios e do Eclesiástico:

Do Livro dos Provérbios, citado exatamente dezesseis vezes, o missionário se refere ao capítulo $31^{4}$, exemplificando a atitude da Perfeita Dona de Casa, "mulher talentosa que vale muito mais do que pérolas", tomada como modelo do tratamento ideal dos escravos coloniais. Um modelo transplantado de uma realidade sociocultural longínqua, a partir de um texto compilado mais ou menos 450 anos a.C.

28. Que bem entendeu esta doutrina aquela Mulher forte tão celebrada nos Provérbios! Por isso as rações que repartia pelas escravas, não as media pelo singular, senão pelo plural: Porque não lhes dava o sustento com mão escassa, mas mui liberal; nem só lhes dava o pão, mas também o conduto. Porque como é possível que o escravo ou escrava, andando em contínua lida e trabalho, sustente a vida com uma ração escassa de farinha de pau, sem outra coisa que a ajude a levar? Se é verdade que não pode o homem sustentar a vida unicamente com pão, ainda sendo o pão de trigo: (BENCI, 1977, p.62).

Além do capítulo 31, o autor recorre à sabedoria de Salomão em outros trechos proverbiais, para bem 'domar' os escravos (muitas vezes reduzidos à condição de 'coisas' e comparados aos animais), segundo os costumes da época:

125. Para trazer bem domados e disciplinados os escravos é necessário que o senhor lhes não falte com o castigo, quando eles se desmandam e fazem por onde o merecem. Diz Salomão nos seus Provérbios: Assim como o ginete necessita da espora e o jumento do freio, para serem governados; assim os imprudentes e maus necessitam da vara e do castigo, para que sejam morigerados como devem, e não faltem à sua obrigação (BENCI, 1977, p. 126).

Porém, é no Eclesiástico, como ele mesmo declara, que vão ser buscadas as premissas da sua essência pedagógica conhecida posteriormente como a pedagogia dos três pês — pão, pano e pau — com o qual os senhores deveriam educar (adestrar) os seus escravos. Sobre o trato com o escravo, o capítulo 33 do Eclesiástico diz o seguinte:

25 Para o asno forragem, chicote e carga; para o servo pão correção e trabalho. 26 Faze teu escravo trabalhar e encontrarás descanso; deixa livre as suas mãos e ele procurará a liberdade. 27 Jugo e rédea dobram o pescoço, e ao escravo mau torturas e interrogatório. 28 Manda-o para o trabalho, para que não fique ocioso, porque a ociosidade ensina muitos males. 29 Emprega-o em trabalhos, como lhe convém, e, se não obedecer, prende-o ao grilhão. 30 Mas não sejas muito exigente com as pessoas e não faças nada de injusto. (ECCLI. 33, 25-33). 
Benci diz, explicitamente, que fundará o seu discurso nessas três idéias que compreendem todas as obrigações que deve o senhor ao servo e que não são poucas. Essa tríade sustento, disciplina e trabalho, aparentemente um dito tão banal será, na verdade, a quintessência pedagógica do tratado do missionário. Desse modo, ao menos aparentemente, a multiplicidade de formas e conteúdos barrocos, desenvolvida por Benci vai estar, em toda a obra, subordinada a essa idéia central que é a pedagogia dos três pês.

8. Mas que obrigações pode dever o senhor ao servo? O mesmo Espírito Santo no-las dirá; o qual distinguindo no Eclesiástico o trato que se há de dar ao jumento e ao servo, diz que ao jumento se lhe deve dar o comer, a vara, e a carga [grifo nosso]: Cibaria, et virga, et onus asino (1) Eccli. 33, 26. Deve-se o pão ao servo, para que não desfaleça, panis, ne succumbat; o ensino, para que não erre, disciplina, ne erret; e o trabalho, para que se não faça insolente, opus, ne insolescat (BENCI, 1977, p. 51).

Um olhar sobre as intenções do autor revela conjuntos variados de categorias pedagógicas, subordinadas à visão de mundo e a sua própria consciência: acerca da licitude da escravidão, acerca dos direitos e dos deveres da Igreja Católica e do Reino Português (sobre as novas terras descobertas) e acerca daqueles que aqui habitavam ou que, para aqui, foram trazidos à força (CASIMIRO, 2002).

O primeiro conjunto, o maior, fundamenta toda a obra, e toma como princípio educacional as categorias do Eclesiástico: pão, disciplina e trabalho, acrescentadas do pão da doutrina. Outro conjunto, que vai aconselhar e explicar exatamente esse 'pão da doutrina' para os escravos é aquele já mencionado, extraído das disposições do Concílio de Trento e que se constituiu nos fundamentos da catequese católica dos séculos seguintes: a Doutrina Cristã, os Sacramentos e o bom exemplo.

\section{As Categorias Pedagógicas Jesuíticas para Senhores e Escravizados}

No presente texto, nos detivemos mais aprofundadamente na análise de uma terceira vertente de categorias pedagógicas preconizadas por Jorge Benci, mas, também, facilmente encontradas em outros textos coloniais. Trata-se de exemplos de comportamento a serem seguidos, ameaças de castigos e a instauração do medo.

O autor, além de apresentar a categoria 'exemplo' como princípio fundamental da catequese tridentina, aconselha o uso do exemplo como categoria pedagógica a ser utilizada na própria ação ensino-aprendizagem. Aconselha diretamente aos senhores e aos párocos que ensinem as orações e os mistérios da fé, com palavras adequadas à compreensão dos escravos, com semelhanças e exemplos palpáveis. Diz assim:

78 [...] Que importa que o Pároco ensine aos escravos as Orações, os mistérios da Fé, e os preceitos da Lei de Deus, se os não propõem com palavras acomodadas á rudeza e pouca capacidade de Negros boçais? Se os não explica e declara, uma e outra vez, para que o entendam? Se não usa de semelhanças e exemplos palpáveis? Se lhes não faz patente aos olhos o mistério, de que não é capaz o entendimento? [...] Devem, para não faltarem a esta obrigação, ensinar uma e muitas vezes a Doutrina; explicar uma e muitas vezes o mistério; e declarar uma e muitas vezes o que ensinam (BENCI, 1997, p.95).

Daí, na melhor forma barroca, o autor se dedica a persuadir, sem economia de palavras, nem de citações, nem de argumentos de autoridades, aos senhores e aos párocos sobre a importância do bom exemplo: 
95. O melhor modo de doutrinar não é com palavras, é com as obras. As obras vêem-se, as palavras ouvem-se: e o que se ouve talvez entra por um ouvido e sai por outro, e o que se vê entra pelos olhos, e, como não tem porta para sair, penetra até o coração. Mais hão-de aprender os escravos em poucos dias da vida exemplar de seu senhor, do que podem aprender em muitos anos de doutrina. Tem muito que andar, quem caminha para a virtude pelo caminho dos preceitos; e a poucos passos se acha no termo quem toma o caminho pelo atalho dos exemplos (BENCI, 1997, p.106).

Para o Jesuíta, o exemplo tem uma qualidade superior ao preceito, pois, suavemente, atrai as vontades para que o imitem, qualidade que falta aos preceitos. Por isso, diz: "tanto que o escravo vê o exemplo do senhor, anima-se a segui-lo". Igualmente, Benci tenta persuadir os senhores comentando os prejuízos materiais e espirituais causados pelos maus exemplos que eles dão:

100 [...] Os escravos, havendo de aplicar algum sentido a seus senhores, aplicariam os ouvidos, para saberem o que deles querem, sendo sua obrigação executar o que lhes mandam; e não os olhos, para verem o que eles fazem. Assim havia de ser, se os escravos no governo de suas vidas se regulassem pelo que lhes dizem seus senhores. Porém, como se não regulam pelo que lhes ouvem dizer, senão pelo que os vêem obrar; bem diz David que os servos põem os olhos nas mãos de seus senhores e as servas nas mãos de suas senhoras. Donde se segue, que os senhores, que querem persuadir aos escravos a exacta observância dos preceitos divinos, devem viver de sorte que vejam neles os mesmos escravos um exemplo e retrato de verdadeiro cristão (BENCI, 1997, p.109).

Todo o texto de Economia Cristã é entremeado de bons exemplos; maus exemplos; exemplos bem intencionados, porém infelizes; exemplos pagãos e bíblicos (principalmente antico-testamentários); e, até mesmo, exemplos trágicos. Dentre os inúmeros bons exemplos citados, a começar pelo topo da hierarquia celestial, o missionário toma como modelo o próprio Deus:

33 [...] Não podia o Senhor mandar a Adão que matasse algumas feras, e que com as peles delas se vestisse a si e a sua mulher? Pois porque lhes faz o mesmo Deus com a sua mão os vestidos, fecit Dominus Deus? A razão está naquela palavra Dominus, Senhor. Porque sendo Deus o verdadeiro exemplar e norma dos senhores, quis satisfazer cabal e perfeitamente à obrigação de senhor. Se Adão caçara as feras, era mostrar que o escravo devia buscar o com que se vestir. Pois não seja assim; corte-lhe o mesmo Deus com sua mão o vestido, já que é Senhor, para que saibam e entendam os senhores que a eles pertence dar o vestido aos escravos, e não aos mesmos escravos o procurá-lo [...] 140 Deus ordinàriamente usa perdoar com facilidade as ofensas próprias e castigar severamente as alheias. Logo se Deus se há desta sorte conosco, com quanta mais razão devem os senhores haver-se da mesma sorte com Deus, castigando nos escravos com maior rigor as ofensas que cometem contra o mesmo Deus do que as que cometem contra eles? Armai, senhores, armai a mão de castigo contra as ofensas, que fazem a Deus os vossos escravos; que nunca pode ser mais bem empregado o castigo (BENCI, 19978, p.136). 
Deus é também o modelo de perfeição a ser seguido na hora de castigar os escravos, pois, na Sua sabedoria, não se deixa levar pela cólera, ao castigar o pecado. Na plasticidade da linguagem hebraica traduzida, Deus, para não se deixar levar pela cólera, 'anda passo a passo', na aplicação do castigo que foi dado a Adão e Eva:

$176[\ldots]$ Os delitos à primeira vista são, mais horrorosos, espantam mais, e acendem mais a ira. E as paixões, assim como os ventos, são em seus princípios mais violentas e arrebatadas. Por isso se lhes deve pôr tempo em meio, e não executar logo o castigo. Nem vos admire, que eu queira de homens sujeitos a paixões, mais vagar no castigo dos servos; pois ainda o mesmo Deus, em quem não pode cair a mínima sombra de cólera ou de paixão, não se acelera, mas anda passo a passo, quando se resolve a castigar (BENCI, 1997, p.160).

Pelo entendimento de Benci, a razão foi porque o Senhor quis ensinar aos senhores que não se acelerassem nos castigos dos servos, mas que castigassem de 'cabeça fria', como já foi mencionado:

177 [...] Não havendo em Deus paixões, quis obrar para nosso exemplo como se estivesse sujeito a elas; por isso não corre, passeia, pondo tempo em meio entre a culpa e o castigo. Imitai, senhores, ao supremo Senhor; e quando houverdes de castigar o servo, ide devagar, deixai que esfrie o calor da indignação, e dai tempo para sossegar a paixão e cólera. Quem dá o castigo apaixonado e colérico, dá como cego; quem dá como cego, não vê por onde dá; e por isso não repara em castigar bárbara e cruelmente (BENCI, 1997, p.160).

Além do Pai, Benci toma também como modelo, o Filho, Jesus Cristo, como os maiores exemplos de perfeição a serem seguidos

$97[\ldots]$ o exemplo de senhor que se faz mestre do servo, o atrai, e incita à imitação; porque havia de dizer que lhe faz força e o obriga. Depois que Cristo lavou os pés a seus Discípulos, lhes disse que tinham obrigação de fazer o mesmo, e lavar os pés uns aos outros. [...] 98 Qualquer outro exemplo é somente incentivo e estímulo para a imitação: logo, que mais tinha o exemplo de Cristo, para passar de estímulo e incentivo a ser obrigação? A razão, o mesmo Cristo a deu: Vós chamais-me Mestre e Senhor: e dizeis bem, porque na realidade o sou. Logo se eu sendo vosso Senhor e vosso Mestre, vos lavei os pés; também vós deveis, e tendes obrigação, de lavar os pés uns nos outros. Reparai bem naquelas duas palavras, Dominus et Magister; porque nelas se encerra todo o fundamento de obrigação. Era Cristo Senhor, e era Mestre; e o exemplo de quem é senhor, e juntamente mestre, não só incita, e estimula, mas quase com força e eficácia de preceito obriga à imitação (BENCI, 1997, p.107).

Na sua visão, só a paciência divina de Cristo para agüentar ações tão desumanas dos senhores cruéis e tiranos, pois, "Em Cristo com as mais virtudes foi também divina a paciência, a qual mostrou em todo o discurso de sua Paixão; porque por mais injúrias que lhe fizeram, e por mais tormentos que lhe deram seus inimigos, se houve sempre como Cordeiro, sem se lhe ouvir em todo este tempo a mínima queixa". Porém, se o castigo é 
sem culpa, até mesmo Cristo o questiona, como exemplifica o autor com o episódio da bofetada que lhe deram na Sua Via Crucis.

131 [...] Se o castigo é merecido, anima-se qualquer a sofrê-lo com paciência e igualdade de ânimo: ver-se porém castigado (e talvez rigorosamente) sem culpa, terrível gênero de dor é este e por todos os princípios, intolerável [...] Que paciência pois há mister um triste escravo para sofrer os castigos, que lhe dá o senhor sem razão e sem causa? Parece-me que há mister uma paciência, não só mais que humana, mas ainda mais que divina (BENCI, 1997, p.129).

Na hierarquia celestial, depois dos exemplos do Pai e do Filho, o jesuíta menciona o conhecido exemplo do Arcanjo São Miguel que, na sua luta contra o demônio, não blasfemara. Querendo mostrar a gravidade do ato de blasfemar contra os escravos, o missionário pergunta:

155 [...] Porque se não havia de atrever S. Miguel a amaldiçoar o demónio, sendo o demónio tão digno de todas as maldições, nem dizerlhe uma palavra injuriosa, não havendo injúria que ele não mereça? Aqui vereis o que são pragas, o que são maldições e o que são nomes injuriosos; que nem contra o mesmo demónio se atreve a proferi-los o Príncipe das jerarquias celestes. E estas pragas, estas maldições, e estes nomes proferis vós tão facilmente a cada passo contra vossos escravos (BENCI, 1997, p.146).

Também os personagens antico-testamentários, os estóicos, reis e rainhas são fontes memoráveis de bons e maus exemplos, principalmente quando se trata de convencer os senhores coloniais a conduzirem a escravidão segundo o modelo clássico. Conforme observamos:

99 [...] Já reparámos na diligência, com que executou Abraão este preceito; agora reparo na prontidão com que o aceitaram os escravos, deixando-se todos circuncidar, sem que houvesse neles a mínima repugnância [...] Quando o senhor pode dizer ao servo: segue-me, que eu vou diante; não recusa o servo de o seguir, ainda que seja por feridas e mortes violentas. Se o senhor vai diante vestido com a púrpura de seu sangue na guarda dos preceitos divinos; não duvida o servo em derramar o das próprias veias, para seguir o exemplo de seu senhor. Observem, pois os senhores exactamente os Mandamentos da Lei de Deus; que na observância, ainda dos preceitos mais rigorosos, não haver servo, que repugne, precedendo com exemplo seu senhor (BENCI, 1997, p.108).

Em Economia Cristã dos Senhores no Governo dos Escravos é lembrada, como não poderia deixar de ser, um dos maiores modelos de virtude cristã: a paciência de Jó

134 Job [...] sendo um senhor e príncipe tão grande entre todos os do Oriente, não tinha por desdouro perguntar e ouvir as razões dos seus servos, quando se punham a juízo com eles. Eu (diz o rei paciente) nunca imitei o costume daqueles senhores, que se desprezam de ouvir aos servos, e nunca lhes tolhi que alegassem sua defensa e dissessem em abono de sua causa, ainda contra mim (BENCI, 1997, p.133). 
Em dualidade antitética, Benci utiliza a idéia do mau exemplo, que não deve ser dado e nem deve ser seguido, por levar à perdição da vida material e da vida espiritual.

101 [...] não vêem [os escravos] exemplos de Cristãos, senão escândalos próprios de Gentios? Que importa que se lhes ensine com palavras o modo com que hão-de viver cristãmente; se a má vida de seu senhor desmente com costumes viciosos a doutrina, que lhes dá. Se um edifica, e outro de faz o mesmo edifício; que hão-de tirar ambos (diz o Espírito Santo) senão o trabalho? E não há-de cansar-se debalde na doutrina dos escravos o senhor, que tudo o que lhes ensina com as palavras, vai desfazendo tom as obras? (BENCI, 1997, p.110).

Quando o missionário se refere a escândalos, está se referindo precisamente aos pecados sexuais e o que fica claro é a sua preocupação com a quantidade de maus exemplos que eram dados aos escravos:

102 [...]como há-de crer o escravo, que é pecado gravíssimo jurar pelo nome de Deus, vendo que seu senhor jura e perjura a cada passo por Deus e pelos Santos, por mais que o mesmo senhor lhe diga que Deus proíbe os juramentos? Como há-de acabar consigo de observar as Festas assistindo ao menos ao Santo Sacrifício da Missa nos Domingos e dias santos, se vê que seu senhor a ouve de ano em ano, por mais que o mesmo Senhor lhe inculque que Deus as manda guardar? Como se há-de capacitar que não é lícito matar ou ferir para se desagravar das injúrias, vendo que seu Senhor por razões de pouca ou nenhuma entidade promete feridas e balas, por mais, que o mesmo senhor lhe intime que Deus ordena que se não cometa homicídio, nem faça outro dano à vida do próximo? Como se há-de persuadir a viver continente e casto, vendo que seu senhor sustenta das portas adentro a concubina, por mais que o mesmo senhor lhe ensine que Deus quer que se guarde castidade? Como há-de assentar consigo não furtar e contentar-se com o que lhe dá seu senhor, vendo que o mesmo senhor não se contenta com o seu, mas busca modos e traças para enriquecer com o alheio, por mais que lhe pregue que na Lei de Deus estão severamente presos os furtos? Fique logo assentado, que toda a mais doutrina, que os senhores derem aos servos, se não for acompanhada do seu exemplo e confirmada com suas obras, não serve de alimento espiritual (BENCI, 1997, p.111).

Mas, o pior exemplo, de todos, que não deve nunca ser seguido, adverte Benci, é o do demônio, que ronda sempre à espreita das almas: "Pois sabei que o senhor, que isto faz (quero dizer, que manda estas embaixadas) não é senhor, é Lúcifer, e tem domínio nos seus escravos do mesmo modo que o tem Lúcifer nos demónios. Lúcifer, bem sabem todos que é o príncipe e senhor do Inferno, e tem poder e domínio sobre os demónios" (1997, p.120). Da mesma forma, não deve ser seguido o exemplo daqueles que se fazem instrumentos do demônio e induzem os servos ao pecado:

110 [...] porque não merece menos castigo, quem é instrumento do demônio para a perdição das almas, senão que venha sobre ele a maldição divina. E notai, que a serpente não foi voluntariamente instrumento do demônio; porque ele se lhe introduziu no corpo, e a obrigou a falar, não sabendo ela o que falava nem o que fazia. E se contudo ainda a amaldiçoou Deus; que fará ao senhor, que se faz instrumento do mesmo 
demônio, livre e voluntariamente e sabendo que faz mal quando induz os servos ao pecado? (BENCI, 1997, p.115).

Como recurso extremo para comover os senhores, Benci usa exemplos de castigos trágicos, como o de um senhor que tiranizava os seus escravos. Como já foi relatado, um desses escravos, para vingar-se das tiranias e do cativeiro, esperou que o senhor saísse de casa. A seguir, fechou por dentro as portas e,

173 [...] tomando pela mão a dois filhos do mesmo senhor ainda meninos, subiu, e os levou consigo ao eirado da casa. Voltou finalmente o senhor, bateu à porta; e porque ninguém lhe respondia, começou, como costumava, a ameaçar ao escravo. Ouviu o escravo, (que para isso estava à espera), e chegando à janela com um dos meninos nos braços, 'disse ao senhor, que se queria a seu filho, que aí lho dava, lançando-lho aos pés feito em pedaços. E logo tomando nas mãos o segundo, perguntou ao Senhor, que lhe daria pela vida daquele filho, que já era o único [...] Mas assim como o senhor se não havia nunca movido ás vozes do servo, quando o castigava; assim o servo se não moveu agora ás vozes e gemidos do senhor. Deixa cair das mãos o menino, e após ele se precipita também a si mesmo, dizendo primeiro estas palavras: Aprende, daqui inumano e cruel senhor, aprende daqui a tratar com piedade os teus servos. Deste exemplo tão raro, e de outros, que cada dia vemos, bem podiam aprender os senhores a usar com os servos de castigos mais moderados do que costumam, e mais sofríveis à fragilidade humana (BENCI, 1997, p.158).

Consoante os rigores da época, Jorge Benci acreditava firmemente na eficácia do castigo como norma pedagógica. Contudo, conforme ele declara, ao mesmo tempo em que os senhores devem dar o castigo, caso haja culpa, deveriam também relevar algumas falhas, e nunca castigar sem culpa.

Quanto à maneira de aplicar o castigo, aconselha que os senhores não devem injuriar, amaldiçoar ou seviciar os escravos culpados. Mas, depois de ouvir o escravo, devem castigar sem raiva e na proporção do erro cometido. Pois, a finalidade da pena corporal deveria ser a reparação da falta, restauração da ordem, emenda do contraventor, exemplo para os outros e desestímulo para cometerem novas faltas. Para Benci, o castigo deveria ser a 'medicina da culpa'.

Além de usar a pedagogia do castigo físico como um princípio fundamental do Eclesiástico, Benci, permeia toda a sua obra, amedrontando e ameaçando os senhores com terríveis castigos das mais variadas sortes. Agrupando essas ameaças e medos, em categorias semelhantes, é possível configurar três tipos que aparecem mais constantemente e, certamente, os mais eficazes no universo mental daqueles senhores do Brasil colonial.

Sutilmente, nos seus discursos, Benci provoca os anseios e os valores daqueles senhores, ameaçando-os com a perda dos seus bens materiais (inclusive perda dos escravos), perda da família, da saúde e da própria vida àqueles que não se conduzem no caminho cristão. Seus discursos trazem exemplos pródigos de ameaças e castigos para os senhores e párocos que não ensinam a doutrina cristã para seus escravos:

82 [...] Estas guerras experimentou já o Brasil no tempo dos Holandeses. Depois lhe ameaçava fomes e esterilidades [...] não há tantos anos que as padecemos? E por mais remédios que se apliquem para que haja abundância, não continua a carestia? Ainda mal, que tudo é verdade. 
Ultimamente lhe ameaçava pestes e mortandades tão formidáveis, que o comum cemitério (chamado vulgarmente inferno) não seria bastante para se sepultarem os corpos dos defuntos. E que destroços e mortes não experimentou a maior parte do Brasil com aquele mortífero contágio da Bicha, cujas cabeças até agora não estão de tal sorte cortadas, que as não vejamos ainda brotar por vezes em febres e doenças mortais? [...] 83 porque culpas havia de mandar Deus ao seu Povo tantos estragos e assolações? [...] porque faltou nele a verdadeira ciência; isto é a doutrina e notícia da Lei de Deus e seus mistérios. Pois se basta esta ignorância de Deus e dos mistérios de sua Fé, para que mereça um Povo escolhido ser castigado com guerras, fomes e pestes; por que não atentam os Párocos e senhores do Brasil, que deixando os escravos naquela ignorância e rudeza, que trouxeram do Gentilismo, chamam e provocam contra o mesmo Brasil todas essas guerras, todas essas fomes, e todas essas pestes? Para evitar pois todos estes castigos e gerais destroços, apliquem os Párocos e Senhores o maior de seus cuidados em dar o pasto espiritual às almas dos Pretos, inculcando-lhes, uma e muitas vezes, a Doutrina Cristã e os mistérios da Fé (BENCI, 1997, p.98).

Benci organiza seus argumentos orientando qual deve ser o procedimento dos senhores com seus escravos. A princípio, devem persuadir sobre a necessidade do comportamento cristão. A seguir, advertir sobre a obrigação do cumprimento das leis civis, religiosas e divinas. E, por fim, devem amedrontar e ameaçar os escravos com castigos, no caso da transgressão ou da inobservância da lei.

Como ele declara e como podemos observar em Benci e em outros textos da época, cada lei religiosa era acompanhada da ameaça do castigo correspondente para quem não a cumprisse. As ameaças de possíveis castigos aparecem no texto em forma de pragas, pestes, doenças, fome, morte, guerra, vinganças dos escravos, perda da família e perda dos escravos - para os senhores que não agissem de maneira cristã. É o que evidenciam outros comentários do Jesuíta:

255 Antes afirma Filo, que pela demasia deste trabalho e excesso dos calores, muitos deles morriam feridos da peste. E não é isto mesmo, o que sucede a cada passo nos escravos dos que querem deles em uma hora o serviço que era para duas, e em um dia o trabalho que era para dois? Ficam os miseráveis tão debilitados e cansados, que a mesma vida se lhes faz penosa e molesta: e vivendo desgostosos e aborrecidos da vida, contraem malignas e outras doenças mortais, com que em breve tempo se livram do cativeiro com a morte [...] 256. Procurem logo os senhores moderar de sorte o trabalho, que este não exceda as forças dos escravos nem o tempo do serviço, porque se assim o não fizerem, e os oprimirem com trabalhos por qualquer caminho exorbitantes, darão os tristes escravos tais clamores ao Céu, que penetrando os ouvidos e o coração de Deus, o obrigarão a descarregar sobre o Brasil os mais rigorosos castigos, como foram os que experimentou o Egipto pelas tiranias que usava com os Hebreus no tempo de seu cativeiro (BENCI, 1997, p. 209-210).

Benci observou que os senhores tinham tanto ou mais pavor de perder a alma e o 'reino dos céus', do que os bens materiais. Assim, além de ameaçar com a perda dos bens terrenos, o que predomina nos seus discursos são as ameaças de perdas espirituais. Ele adverte os senhores contra a ação (influência) do demônio, que pode levar o cristão ao 
pecado, causar ofensa a Deus, desencadear a ira e o castigo divinos, para, finalmente, levar à perdição da alma e ao fogo eterno_do inferno.

$\mathrm{Na}$ Obra, essa articulação foi feita didaticamente em todos os discursos. Como exemplo, no Parágrafo V do Discurso II, Benci encadeia uma série de ameaças cujos efeitos devem ter sido inquestionáveis na imaginação dos ouvintes dos seus sermões e dos leitores da sua obra. Para os senhores que escandalizavam os escravos, o missionário advertia primeiramente contra o pecado:

104 pecarão fazendo-lhes positivamente o maior mal, qual, induzi-los ao pecado? Mas, para que melhor se conheça a deformidade destas induções ou destes pecados de escândalo, quatro coisas havemos de ponderar neste parágrafo. $\mathrm{O}$ dano, que com eles fazem os senhores ás almas dos seus escravos; o grande serviço, que fazem ao demônio, o mal, que se causam a si mesmos; e a injúria, que fazem a Cristo [...] 105 quando por qualquer modo os induzem a pecar, não só é o maior, mas é o sumo dano. O maior dano, que pode fazer qualquer senhor a um servo, é tirar-lhe a vida; mas suposto que este é o maior, não é sumo: $\mathrm{O}$ sumo e maior de todos os danos, que lhe pode fazer, é induzi-lo a pecar [...] (BENCI, 1997, p.113).

Depois, ele acusava os senhores que escandalizavam os escravos principalmente porque incorriam em pecado e, pior que isso, ofendiam a Deus e a Cristo.

106 [...] o pecado é ofensa de Deus; e o culto e veneração que devem as criaturas ao mesmo Deus pede que antes se de perder a vida, do que cometer um pecado. Sendo pois o pecado maior mal que a mesma morte; não podem negar os senhores que maior dano fazem aos servos induzindo-os a pecar, do que tirando-lhes a vida matando-os; porque matando-os, tiram-lhes a vida do corpo; e induzindo-os a pecar, tiramlhes a da alma; e quanto vai da, alma ao corpo, tanto vai de dano a dano, e de pecado a pecado (BENCI, 1997, p.113).

Seguindo o mesmo raciocínio, ele alertava, sobre o modo como o demônio andava à espreita, como um leão faminto à procura de sua presa:

107[...] tão ansioso o demônio em procurar que os homens pequem, que S. Pedro o compara ao leão faminto, que segue e persegue as feras para as tragar. Notai muito aquela palavra, circuit, que significa própriamente andar à roda e voltear uma e outra vez. E assim faz o demônio após de uma alma. Anda continuamente à roda e em seguimento dela; dá uma volta e outra volta; não, desiste de a tentar freqüentemente, até que ia vence e rende á sua vontade, fazendo-a cair na culpa e acrescentar pecados sobre pecados (BENCI, 1997, p.114).

O missionário culmina este parágrafo, amedrontando os destinatários da sua obra com a possibilidade irrecuperável de perder a alma, para sempre, no 'fogo do inferno':

108. Colhei agora daqui o grande serviço que faz ao demônio o senhor, que escandaliza aos escravos induzindo-os a que pequem; pois tira ao mesmo demônio o trabalho de andar tão sem sossego após das almas, entregando-lhas (como dizeis) ás mão lavadas, e dando o melhor dia ao Inferno. Quando um pecador se arrepende e faz penitência, diz Cristo que há grandes festas no Céu. E porque não haverá no Inferno alegrias, 
quando uma alma se arroja ao pecado e perde a graça, sendo tão oposto o inferno ao Céu? [...] 109. O mal que se causam a si os mesmos senhores com os seus escândalos, é o mesmo que o que causam aos servos; porque assim como aos servos lhes procuram a morte da alma, essa mesma procuram também para si, e para si sempre certa; porque pode não o servo, ainda que induzido do senhor; e sempre peca o senhor que induziu ao servo. Mas além de tudo isto se faz digno da maldição tremenda de Deus, por ser instrumento do demônio, na perdição e ruína das almas (BENCI, 1997, p.115).

Os outros discursos seguem sempre a mesma tônica, com insistência nas categorias da ameaça e do medo de castigos, sempre na mesma ordem: medo do demônio, do pecado, medo de ofender a Deus ou a Cristo, medo do castigo divino, da perdição da alma e do fogo do inferno. Vez por outra aparecem outras categorias como o medo de ser homicida ou o medo do juízo final, mas, em escala bem menor:

56 [...] E com estas obras de misericórdia e com estas visitas de enfermos haveis de aparecer diante do tribunal de Cristo no dia do Juizo? Se usásseis desta inumanidade com qualquer outro pobre estranho (a quem ùnicamente pede a Caridade que se socorra na necessidade extrema, qual é a de uma grave doença) e lhe faltásseis com o remédio, não havíeis de ser julgados para o Inferno? [...] se um dos cargos, que Jesus Cristo fará aos réprobos no dia do Juizo, será também que estando enfermo na pessoa dos pobres o não visitaram (BENCI, 1997, p.79).

Assim como ele adverte sobre a obrigação do cumprimento das leis civis, religiosas e divinas, introduz ameaças de castigo, pelo não cumprimento dessas mesmas leis. Ameaças escolhidas a dedo pelo Jesuíta, que se mostrou um perspicaz conhecedor dos temores reinantes no imaginário colonial.

Geralmente ele começava o sermão (e o texto) ameaçando e amedrontando os senhores com a possibilidade de castigo civil; recrudescia com a perspectiva do castigo canônico; e concluía com a promessa de terrível castigo divino para aqueles senhores que não conduzissem seus escravos de acordo com as normas cristãs, ou seja,

49 as Leis Civil e Canônica; as quais em pena do grave delito que cometem os senhores desamparando aos servos no tempo da enfermidade e lançando-os bárbaramente de casa para os não curarem, decretaram que os mesmos senhores perdessem o domínio que tinham nos servos desamparados, e estes ficassem livres e forros. Ouvi como gravemente fala o Direito Civil: Se alguém lançar de casa ao seu servo enfermo, e o puser na rua, não tratando de o curar, ou não dando comissão a outrem para que lhe assista; este tal servo, ainda contra vontade de seu senhor, consiga no mesmo ponto a liberdade, e seja tido e havido por cidadão romano [...] 50 e o Direito Canônico; o qual depois de declarar, que o pai que enjeita o filho, perde o domínio paterno, que nele tinha; e o senhor que enjeita o escravo, perde o senhorio, que nele tem; acrescenta, que o mesmo se há-de dizer dos filhos e dos escravos, de qualquer idade que sejam, quando são expostos e desamparados dos pais, e senhores em suas enfermidades Vede logo se com razão dizia eu, que se fazem indignos do senhorio os que não tratam da cura dos seus servos enfermos; pois o Direito os julga tão indignos do domínio a respeito dos servos, que lhes tira todo o que neles tinham (BENCI, 1997, p.76). 
Pela concepção pedagógica do Jesuíta, aquele que incorre no pecado, por conta própria ou induzido por outrem (recebendo mau exemplo), ou aqueloutro que leva um terceiro a pecar (dando mau exemplo) serão castigados. Pois, quem dá mau exemplo ou quem segue mau exemplo também incorre em pecado, merecendo a ira divina e o castigo. $\mathrm{Na}$ sua visão, fica posto que os castigos pelos pecados cometidos, tanto podem ocasionar perdas materiais (perda dos filhos, dos bens, perda dos escravos, doença, peste etc.) como podem ocasionar a perda espiritual, da alma e, conseqüentemente, o castigo divino do fogo do inferno (o mais temido naquela época).

\section{A Retórica Jesuítica no Sermonário Colonial}

As ameaças e os medos de castigos, imputados aos senhores, aparecem na fala do missionário, assim como apareceram nas falas de outros congêneres, coloridos com diversas tonalidades que vão desde as acusações, comparações, exemplos, advertências, admoestações, até chegar aos conselhos, exortações, e persuasões.

Qual a razão de tanta retórica? É provável que, além de permanecer dentro do estilo literário usual da época, ele tivesse a certeza de que tais tonalidades tornariam os seus discursos mais inteligíveis para aquela clientela especial. Ademais, acreditava firmemente estar contribuindo para modificar as relações de trabalho entre os senhores e os escravos do Brasil setecentista. Nas suas variações argumentativas, observamos facilmente as mudanças de tom com que ele se dirige aos destinatários da sua Obra:

Tom acusativo: "Senhores há que não faltam aos escravos com a ração quotidiana; mas esta é tão limitada e escassa, que mais serve para que não morram de fome do que para que sustentem a vida" (p.61); Comparativo: "é contudo tal a crueldade de alguns senhores, que até o sustento, que tão liberalmente dão aos animais brutos, negam aos cativos" (p.55) "Comparou Plutarco o trabalho à água, dizendo que como as plantas com a água sendo moderada se alimentam, e sendo muita se corrompem; assim com o trabalho moderado se aumenta nos homens o vigor, e com o demasiado se oprime" (p.205); de exemplo: "o exemplo tem uma qualidade oculta, com que suavemente atrai as vontades, para que o imitem; e esta qualidade falta aos preceitos. Por isso, tanto que o escravo vê o exemplo do senhor, anima-se a segui-lo" (p.106); de advertência: "Peca mortalmente o senhor, que tendo algum servo convertido de novo à Fé, não trata de lhe ensinar, ou por si ou por outrem, a Doutrina cristã" (p.85); admoestativo: "Dizei-me, senhores meus: onde vivemos? Em Berberia entre os Mouros de Argel ou no Brasil entre os Cristãos da Baía? Já vejo que me respondeis que entre os cristãos. E haverá algum Cristão, que não saiba que Deus manda santificar as festas e guardar os dias santos; e que é pecado mortal, fora do necessário e preciso, mandar que se trabalhe nestes dias? (p.58); Conselheiro: "Deixai os nomes, as maldições, e, as pragas, e dai ao servo o merecido castigo; porque com aquelas o injuriais e pecais não só contra a Caridade, mas também contra a justiça; e com este, além de fazerdes uma obra de misericórdia, alcançareis a emenda do escravo, que é o fim pelo qual se lhe dá o castigo" (p.152); exortatório: "Aprendei, senhores, deste Centurião da coorte romana [...] Aprendei, digo, a misericórdia e compaixão para com os servos e servas, e o cuidado e desvelo, com que os deveis tratar, quando adoecem e enfermam..." (p.78); persuasório: "o objecto mais próprio e para onde mais deve inclinar a piedade Cristã, são os enfermos, e com singularidade os servos, por ser maior o seu desamparo nas doenças; pois chegando o escravo ao lamentável estado de enfermo não há bem algum, de que não fique privado" (BEBCI, 1977, p.78). Essa última tonalidade de voz, 'persuasória', perpassa, sobremaneira, todos os discursos.

Benci passou pela condição de aluno, noviço e, foi mestre da Companhia de Jesus. Em seu ambiente, conheceu, por inteiro, as teorias e as práticas desenvolvidas nos colégios 
e seminários da Ordem. Assim, tanto sabia aconselhar àqueles senhores escravocratas a dosarem adequadamente os conteúdos doutrinários que deveriam repassar para os escravos, como sabia, ele mesmo, dosar os conteúdo dos seus discursos, para extrair o máximo de efeito possível das consciências coloniais.

Nesse aspecto, fazem parte de uma mesma matriz de raciocínio, suas advertências acerca da moderação nos trabalhos (imputados aos escravos), moderação nos castigos (que deveriam ser de acordo com o tamanho da culpa). E, no âmbito pedagógico-doutrinário, suas advertências acerca da moderação na dosagem dos conteúdos, a serem administrados na catequese aos escravos.

Além das categorias pedagógicas analisadas, um olhar mais atento revela outras categorias que dizem respeito à própria atitude a ser tomada pelo educador (no caso, o catequizador). Categorias estas que por sua vez são reveladoras da excelente formação pedagógica ministrada na formação dos próprios quadros jesuíticos. Moderação e adequação quanto à quantidade de trabalho, ao tempo e à condição física de cada escravo; constância; paciência, perseverança, clareza e sentimento cristão. Alguns exemplos atestam a coerência do pensamento de Benci, na moderação do trato com os escravos:

246 [...] trabalho aos servos, como os medicamentos aos enfermos: isto é, em sua medida [moderação no trabalho]. Porque assim como a medicina tomada em sua conta é remédio que cura as doenças e preserva de achaques e tornada fora dela não deixa de ser perniciosa e causar graves danos; assim também o trabalho dado e tomado em sua proporção, purga dos vícios aos servos e os preserva da rebeldia e insolência contra seu senhor, opus, ne insolescat; dado porém fora da justa medida, debilita-os, enfraquece-os e mata-os [...] 248 Não vos pareça que vos peço muito, pedindo-vos que no trabalho dos servos não excedais os limites da razão; pois não vos peço mais do que (o que) o justo e recto dono costuma fazer com os seus jumentos [...] 250 pôr os olhos nas forças dos mesmos servos, repartindo-lhes as tarefas segundo as forças de cada um. [...] Há escravos, que podem mais, e há escravos, que podem menos: em uns há forças e talento para resistir a muito; outros a pouco trabalho se rendem. Sendo pois desiguais nas forças; porque hão-de correr no serviço a mesma parelha? [...] 253 olhar o senhor para o tempo do trabalho, para o proporcionar de sorte com ele, que não dê ao escravo maior tarefa da que pode acabar suavemente no tempo que tem para o trabalho. Porque querer que o servo faça, exempli gratia, em um dia o serviço que ao menos requeria dois, é tirania própria de senhores crueis e bárbaros (BENCI, 1997, p.204-208).

$\mathrm{Na}$ dosagem dos conteúdos catequéticos, Benci aconselha que os senhores deveriam inculcar a doutrina cristã e os mistérios da Fé, uma e muitas vezes, atentando para a 'pouca capacidade' de aprendizagem do escravo e para o fato de serem 'novamente' convertidos à fé (neófitos). Sobre este assunto, vê-se claramente que Benci fala como pedagogo, portador de um verdadeiro arsenal teórico-prático no campo da pedagogia da sua época. Mas, infelizmente, sempre julgando os negros como 'pouco capazes'. Dirigindo-se aos párocos, ele admoesta sobre os conteúdos doutrinários incompletos, ou ministrados às pressas, sem avaliar se houve realmente entendimento por parte dos alunos:

77 [...] Nem cuidem os Párocos que satisfazem à sua obrigação não mais que só com perguntarem pela Quaresma aos escravos, no tempo da desobriga, se sabem as Orações e os Mandamentos da Lei de Deus; e 
vendo que os sabem ou, para melhor dizer, que os rezam (pois muitos os rezam sem saberem o que rezam) logo sem mais outra doutrina os admitem aos Sacramentos. Este certamente não é o modo, com que devem ser doutrinados estes rudes; porque não está o ponto em que os escravos digam quantas são as Pessoas da Santíssima Trindade e rezem o Credo e os Mandamentos e mais Orações; mas é necessário que entendam o que dizem, percebam os mistérios que hão-de crer, e penetrem bem os preceitos que hão-de guardar (BENCI, 1997, 94).

Benci aconselha uma aprendizagem gradativa que não pode ser realizada em poucos dias. Aconselha constância, perseverança, paciência e clareza. Esses aspectos do seu discurso evidenciam uma preocupação pedagógica positiva dos missionários, principalmente dos jesuítas, cujas técnicas passavam por etapas gradativas em que ensinavam os índios a língua, a cantar, a dramatizar, a dividir nos dedos das mãos os dez mandamentos (respeitando a estrutura mental do negro) e, concomitantemente, a doutrina.

Eram os mesmos conteúdos doutrinários iniciais destinados aos brancos, mas, adaptados às condições dos negros. Sobre a dosagem dos conteúdos, deveria ser administrada aos poucos, adequadamente, principalmente por causa da 'rudeza' dos negros. Para Benci, a pouca capacidade do negro para aprender era uma característica da raça. Ele não vinculava as dificuldades encontradas pelos negros à condição cultural anterior ou à condição da escravidão (que avilta e o faz reagir de forma autodefensiva). Os exemplos que se seguem são magníficos para essa constatação, a despeito da visão pejorativa do autor sobre a capacidade de aprendizagem dos negros, fortemente impregnados nas suas idéias:

78. O pão da Doutrina Cristã deve-o repartir o Pároco a estes ignorantes, tão bem partido e esmiuçado, que o possam comer e digerir. Os pequenos pediram pão, e não houve quem lho partisse, para que o pudessem comer. Mas que pequenos são estes, e que pão é o que pedem? Os pequenos, na frase da Escritura, não são somente os de pouca idade, mas também os de muita, quando são novamente convertidos à Fé. [...] Que importa que o Pároco ensine aos escravos as Orações, os mistérios da Fé, e os preceitos da Lei de Deus, se os não propõem com palavras acomodadas á rudeza e pouca capacidade de Negros boçais? Se os não explica e declara, uma e outra vez, para que o entendam? Se não usa de semelhanças e exemplos palpáveis? Se lhes não faz patente aos olhos o mistério, de que não é capaz o entendimento? Porque a todas estas pensões e explicações estão obrigados os Párocos, pois livremente tomaram à sua conta o cuidado das Almas das suas Ovelhas. Devem, para não faltarem a esta obrigação, ensinar uma e muitas vezes a Doutrina; explicar uma e muitas vezes o mistério; e declarar uma e muitas vezes o que ensinam (BENCI, 1997, p.95).

O uso dessas categorias de moderação no trato e de dosagem dos conteúdos, na relação ensino-aprendizagem, é muito significativo para fazer ver a ambivalência dos sentimentos de Benci a respeito da escravidão. Na sua mentalidade religiosa, estavam sempre presentes as seguintes dúvidas: poder-se-ia escravizar? Sim; dever-se-ia escravizar? Não. Mas, já que a escravidão era um fato dado e estava legalmente instituída, deveria ser mais humanizada, e o escravo deveria ser tratado como próximo. Ademais, se o escravo iria ser cristianizado, ele exortava os senhores e os párocos para que usassem de todos os recursos para a eficácia da evangelização. 


\section{Considerações Finais}

No Brasil Barroco, prevalentemente no século XVIII, as relações entre a religião católica e a educação apresentaram uma convergência fortíssima e se tornaram mais estreitas, ainda, porque eram mediadas pela expressão barroca. É o modo de organização material daquela formação e das formas de organização social que vão proporcionar idéias, conhecimentos e arte homólogas, ou seja, capacidades mentais e formas de pensamento homólogos, em especial, no que respeita à tríade religião educação e arte.

Nesse ambiente, a arte barroca, por meio dos seus sermões, literatura, música e artes plásticas, encontrou terreno fértil para se expandir, influenciando e sendo influenciada pelo meio no qual se desenvolveu. E a Companhia de Jesus foi uma das ordens mais representativas para dar expressão a essas mediações. Os jesuítas pregaram, registraram seus sermões em forma de livros, editaram inúmeras obras de teologia moral, cartilhas, manuais catequéticos, músicas e obras plásticas de tal sorte que é possível conhecer de maneira significativa essas categorias.

Do texto analisado, que reproduz, em parte, a totalidade da ação educacional dos jesuítas no Brasil, as categorias pedagógicas extraídas revelam conteúdos advindos de pedagogias remotas: estóicas, patrísticas e escolásticas, adaptadas à situação colonial. Revelam, outrossim, a própria razão de estudos dos jesuítas. A ação pedagógica dos padres da Companhia de Jesus, fundamentada nos bons nos maus exemplos, nos medos, nos castigos (reais e imaginários), na moderação, na dosagem de conteúdos, era transmitida aos senhores e aos párocos a partir de sermões que adquiriam várias tonalidades: advertências, comparações, acusações, admoestação, exortação, conselhos e persuasão. Ao lado disso, era considerável a importância dada ao sentimento e à atitude do educador: constância, perseverança, paciência e clareza. Tudo isso no mais puro estilo barroco, o mais adequado para ser compreendido naquele tempo e lugar.

Além das razões explícitas, que residiam na evangelização dos negros da terra (gentios) e dos escravizados africanos, tais categorias pedagógicas foram eficazes, também, na conscientização dos senhores para melhor preservação da mão-de-obra escrava, na submissão dos povos dominados e na catalização de conflitos decorrentes daquela sociedade violenta. A análise dos textos aqui apresentados confirma o que já é tese sobre a missão evangelizadora da Igreja Católica no Brasil e da Companhia de Jesus: Eles vinham com a missão de "Dilatar a Fé e o Império"

\section{Referências}

ANTONIL, André João. Cultura e Opulência do Brasil. Est. Bibliogr. Por Affonso Taunay; notas de Fernando Sales. Belo Horizonte: Itatiaia; São Paulo: EDUSP. 1982 (Reconquista do Brasil; nova série; v. 70).

ÁVILA, Afonso. O Lúdico e as Projeções do Mundo Barroco. São Paulo: Perspectiva, 1980. (Debates).

BENCI, Jorge. Economia Cristã dos Senhores no Governo dos Escravos (livro brasileiro de 1700) (Estudo preliminar) Pedro de Alcântara Figueira; Claudinei M.M. Mendes. São Paulo: Grijalbo, 1977.

BÍBLIA DE JERUSALÉM. São Paulo: Paulus, 1995.

CASIMIRO, Ana Palmira B.S. Economia Cristã dos Senhores no Governo dos Escravos: uma proposta pedagógica jesuítica no Brasil colonial. Salvador: Faculdade de Educação/UFBA, 2002 (Tese de doutoramento). 
HOORNAERT, Eduardo. A Cristandade durante a Primeira Época Colonial. In: Hoornaert, Eduardo et al. História da Igreja no Brasil. Tomo II, v. 1. Petrópolis, Vozes, 1983.

A Evangelização do Brasil Durante a Primeira Época Colonial. In: Hoornaert, Eduardo et al. História da Igreja no Brasil. Tomo II, v. 1. Petrópolis, Vozes, 1983.

ORDENAÇÕES FILIPINAS: LIVRO II e III. Lisboa: Fundação Calouste Gulbenkian/ Fac-símile. (Ed.) Cândido Mendes de Almeida. Rio de Janeiro, 1870.

ROCHA, Manoel Ribeiro. O Etíope Resgatado, Empenhado, Sustentado, Corrigido, Instruído, Libertado: discurso teológico-jurídico sobre a libertação dos escravos no Brasil. (1758). (Introd. e notas) Paulo Suess. Petrópolis: Vozes; São Paulo: CEHILA, 1992.

VAINFAS, Ronaldo Trópico dos Pecados: moral sexualidade e inquisição no Brasil Colonial. Rio de Janeiro: Campus, 1989.

VIDE, Dom Sebastião Monteiro da. Constituições Primeiras do Arcebispado da Bahia. (Impressas em Lisboa no ano de 1719, e em Coimbra em 1720). São Paulo: Tip. 2 de Dezembro, 1853.

VIEIRA, Antônio (S.J.) Sermões Prégados no Brasil II: A Vida Social e Moral na Colônia. (Org. e notas) Hernani Cidade. v. III. Lisboa: República Portuguesa; Ministério das Colônias; Divisão de Publicações e Bibliotecas; Agência Geral das Colônias. 1940.

${ }^{1}$ Doutora em Educação, professora da Universidade Estadual do Sudoeste da Bahia - UESB.

E-mail: apcasimiro@bol.com.br.

${ }^{2}$ Cf. nas Referências as obras de Antônio Vieira, Manoel Ribeiro Rocha e Antonil.

${ }^{3}$ Com autorização da Companhia de Jesus e Imprimatur da Igreja Católica. Dessa forma, a Economia Cristã reflete a concepção pedagógica da Igreja e dos Jesuítas.

${ }^{4}$ Perfeita Dona de Casa: Quem encontrará a mulher talentosa / Vale muito mais que pérolas / Noite ainda, se levanta / Para alimentar os criados. E dá ordens às criadas.../ Estende a mão ao pobre, e ajuda o indigente. / Se neva, não teme pela casa, / porque todos os criados vestem roupas forradas.../ Vigia o comportamento dos criados, / E não come pão no ócio / Abre a boca com sabedoria / E sua língua ensina com bondade / Muitas mulheres ajuntaram riquezas, / Tu, porém, ultrapassas a todas. / Enganosa é a graça, fugaz a formosura, / Dailhe parte do fruto de suas mãos, / E nas portas louvem-no suas obras (PROV. 31, 21-2).

Artigo recebido em: 18/01/10

Aprovado para publicação em: 05/03/10 